\title{
BENTHIC NUTRIENT FLUXES ACROSS A PRODUCTIVE SHELF ADJACENT TO AN OLIGOTROPHIC BASIN: CASE OF THE NORTHEASTERN MEDITERRANEAN SEA
}

Ismail Akcay ${ }^{*}$, Süleyman Tuğrul and Mustafa Yücel

Middle East Technical University, Institute of Marine Sciences, P.O. Box 28, 33731 ErdemliMersin, Turkey

ismail@ims.metu.edu.tr

\section{Highlights}

- Porewater and sediment biogeochemistry were studied in the Northeastern Mediterranean Sea.

- A series of redox reactions (oxic respiration, denitrification, iron reduction) take place in the Northeastern Mediterranean subseafloor.

- Diffusive nutrient fluxes contribute remarkable fraction to total nutrient budget in the study region.

\begin{abstract}
The Coastal ecosystem of the Northeastern (NE) Mediterranean has been affected by nutrient inputs originated from regional rivers and wastewater discharges leading to development of eutrophication. Atmospheric nutrient inputs have also remarkable contribution to marine nutrient pool in the NE Mediterranean, especially in dry periods. Sediment porewater nutrient fluxes into the deep waters are strongly associated with eutrophic and suboxic/anoxic conditions. There was only limited number of studies performed on the porewater and solidstate sediment biogeochemistry in the NE Mediterranean Sea having oxic conditions in the deep waters. In this study, therefore, sediment porewater (PW) nutrient $(\mathrm{Si}, \mathrm{N}, \mathrm{P})$ and sediment organic matter biogeochemistry were studied. The study results indicated a series of redox reactions (oxic respiration, denitrification, iron reduction) as well as remarkable contribution of porewater diffusive nutrient fluxes to the total nutrient budget in the NE Mediterranean Sea. Lower Si/N and higher N/P molar ratios in the total nutrient inputs are very likely to modify phytoplankton composition and abundance in the phosphorus deficient NE Mediterranean productive shelf waters leading to development of mesotrophic/eutrophic conditions in the NE Mediterranean Sea.
\end{abstract}

Keywords: Sediment organic matter, porewater nutrients, nutrient fluxes, Northeastern Mediterranean Sea 
This paper is a non-peer reviewed preprint submitted to EarthArXiv.

\section{Introduction}

The Mediterranean Sea is an oligotrophic sea due to limited nutrient inputs to its sunlit surface from internal and external sources (UNEP, 1989; Y1lmaz and Tugrul, 1998; Kress and Herut, 2001; Krom et al., 2004; Tugrul et al., 2016; 2018). Surface dissolved inorganic nutrient concentrations in offshore waters of the Northeastern Mediterranean (NE) Sea (Figure 1) are measured as low as for inorganic phosphate and nitrate during the springautumn period (Y1lmaz and Tugrul, 1998) and increased slightly in winter due to vertical mixing (Y1lmaz and Tugrul, 1998; Dogan-Saglamtimur and Tugrul, 2004, Tugrul et al., 2016 and references therein). Furthermore, atmospheric nutrient inputs, both dry and wet deposition, have remarkable contribution to sustain primary productivity in the Northeastern Mediterranean (Kocak et al., 2010; Kocak, 2015). For example, contribution of P fluxes to the algal production was calculated as high as $0.9 \%$ in offshore waters of the Cilician Basin of the Northeastern Mediterranean whereas $\mathrm{N}$ fluxes would sustain $8.4 \%$ of primary production in offshore waters and the contribution of atmospheric nutrient fluxes would become drastically high during the stratified summer-autumn period (Kocak, 2015). In the lownutrient upper layer waters of the Mediterranean Sea, primary production is mainly limited by phosphorus due to unusually high $\mathrm{NO}_{3} / \mathrm{PO}_{4}$ ratios in the deep waters as $\sim 28: 1$ (Krom et al., 1991; Y1lmaz and Tugrul, 1998) and in atmospheric and regional rivers (Kocak at al., 2010) as also reported recently by the ${ }^{14} \mathrm{C}$ bioassay experiments conducted in the Turkish coastal waters of the Mediterranean and Aegean Seas (Tufekci et al, 2013). Though low nutrient concentrations in offshore waters of the NE Mediterranean (Figure 1) are recorded in the upper layer, its coastal ecosystem is highly fueled by terrestrial nutrient and organic matter inputs from the major rivers and wastewater discharges leading to development of coastal eutrophication in the inner bay waters (Dogan-Saglamtimur and Tugrul 2004; Tugrul et al., 2009; 2011; 2016; 2018). In the offshore waters of the NE Mediterranean, for example, concentrations of total phosphorous (TP) and Chlorophyll- $a$ were as low as $0.05-0.07 \mu \mathrm{M}$ for $\mathrm{TP}$ and $0.02-0.05 \mu \mathrm{g} / \mathrm{L}$ for Chl- $a$, reaching to peak values in eutrophic coastal waters (Tugrul et al., 2011; 2016;2018).

Organic matter geochemistry of the sediments has been affected by a series of redox reactions (Jørgensen, 1996) as well as terrestrial inputs of the particulate inorganic/organic matter that might be transported to offshore regions of the continental seas (Middelburg et al., 1993; Yemenicioglu and Tunc, 2013; Erdogan, 2014; Akcay, 2015, Ermiş, 2017; Deininger and Frigstad, 2019; Katz et al., 2020). In the Eastern Mediterranean Sea, surface sediment 
geochemistry and grain size distributions have been studied extensively during the last decades (Eijsink et al., 2000; Yemenicioglu and Tunc, 2013; Erdogan, 2014, Akcay, 2015; Ermiş, 2017) with the limited number of studies based on sediment core samples to understand organic matter geochemistry (sedimentation, degradation, accumulation and burial of organic carbon) of the upper 25-40 cm sedimentary column (Van Santvoort et al., 2002; Katz et al., 2020).

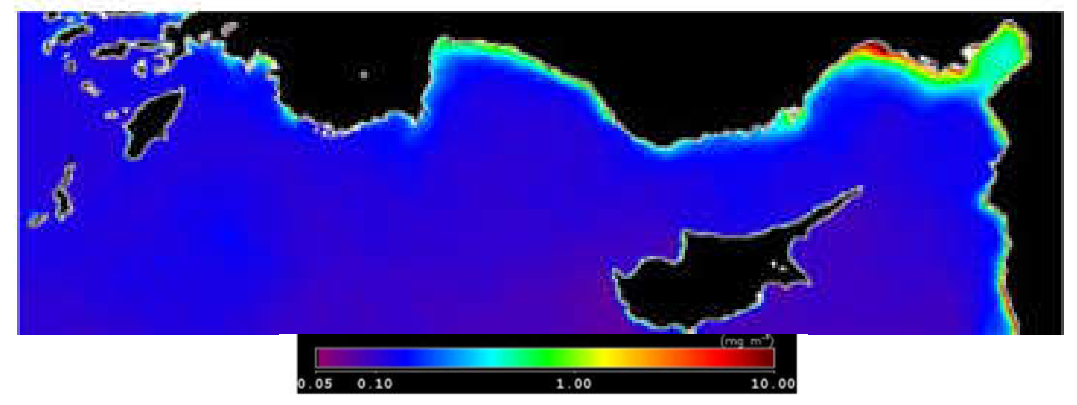

Figure 1. Annual surface chlorophyll- $a$ distribution of the NE Mediterranean shelf waters, obtained by MODIS Satellite in 2009 (modified after Tugrul et al., 2016).

Biogeochemical cycling of key nutrients $(\mathrm{N}, \mathrm{P})$ is highly coupled to oxygen concentrations and metal (Fe, Mn) cycles (Williams, 1987; Jørgensen, 1996). The increase in dissolved inorganic phosphorous and iron concentrations in the Oxygen Minimum Zones (OMZs) is highly related to anoxic conditions in the marine environment as the role of sediments in the OMZs is important for dissolved iron and inorganic phosphate sources to the bottom water (Noffke et al., 2012). Furthermore, in the eutrophic and hypoxic/anoxic Baltic Sea, the intrusion of oxygen-rich North Sea waters into the Eastern Gotland Basin decreased to releases of inorganic phosphate and ammonium from deep sediments (Sommer et al., 2017). Since the cycles of oxygen, phosphorous and nitrogen are highly coupled, ongoing eutrophication in the Baltic Sea induced hypoxia resulting in internal phosphorous loading due to changing redox state of the seafloor (Vahtera et al., 2007; Ferreira et al., 2011; Malmaeus et al., 2012; Noffke et al., 2012). Seafloor can, therefore, play a key role in rapid degradation of labile organic matter and nitrification/denitrification processes as well as other abiotic processes in the uppermost millimeters of sediment layer resulting in nutrient releases from the sediments studied extensively during the last decades (Christensen et al., 1988; Ignatieva, 1999; Rasheed, 2004; Al-Rousan et al., 2004; Hille et al., 2005; Rasheed et al., 2006; Rydin et al., 2011; Cheng et al., 2014; Mu et al., 2017). However, there was only limited number of studies performed on the sediment biogeochemistry and porewater nutrient 
dynamics in the oligotrophic NE Mediterranean Sea having oxic conditions in the deep waters though redox-dependent benthic nutrient fluxes would enhance algal production in the oligotrophic marine basins (Christensen et al., 1988; Ignatieva, 1999; Rasheed et al., 2006). For example, in a study conducted in the oligotrophic Eastern Mediterranean continental shelf, the phosphate and nitrate fluxes into the water column supported as much as $11.7 \%$ and $2 \%$ of the phytoplankton $\mathrm{P}$ and $\mathrm{N}$ demand, respectively (Christensen et al., 1988). Therefore, studying both external (riverine, wastewater, atmospheric inputs) and internal (sediment, submarine groundwater) nutrient fluxes into the oligotrophic and eutrophic marine environments is critical to understand biogeochemical cycling of key elements for further use in biogeochemical modeling and eutrophication management efforts.

The objectives of this study are, therefore, i) to generate a first-time dataset resolving vertical downcore porewater nutrients ( $\mathrm{Si}, \mathrm{DIN}, \mathrm{DIP})$ and solid state sediment geochemical (Carbon; $\mathrm{C}$, nitrogen; N, reactive iron; r-Fe) properties, ii) based on this novel dataset, to estimate sediment porewater diffusive nutrient fluxes to the bottom waters and iii) to determine riverine and wastewater nutrient fluxes, v) to compare both external (riverine, wastewater and atmospheric (Kocak et. al., 2010) inputs) and internal (sediment PW diffusive inputs) nutrient fluxes in the NE Mediterranean shelf waters.

\section{Methodology}

The study area is located at the NE Mediterranean Sea (Figure 2). Field studies were carried out using R/V Bilim-2 of METU-IMS. Sediment core samples were obtained from the five stations (Table 1) in March-April 2018 by a multi-corer sediment sampling device (Oktopus, Kiel). The multi-corer is a sediment sampler used in marine research for the transition zone between the sediment and the near bottom water. By using a dampener, the tubes penetrate the sediment slowly and samples can be collected while causing only minimal swirling on the surface layer. For the extraction, lids close the core tubes with special seals and prevent the samples from escaping. The obtained samples were taken out on board and the sediment samples were sliced by layers on board by means of an extruder. The sediment core samples were obtained from 5 unique locations in the Cilician Basin of the NE Mediterranean Sea. These locations include a small-river influenced region (Lamas River), shelf break and offshore regions in the March 2018 and a large-river Göksu River influenced coastal region, shelf break and one deep reference station (Depth: 1165 m) in April 2018 (Figure 2, Table 1). Porewater extraction procedure of the collected samples was performed as described by the 
This paper is a non-peer reviewed preprint submitted to EarthArXiv.

studies of Christensen et al. (1988), Sundby et al. (1992), Rasheed et al. (2006), Gao et al. (2008), Noffke et al. (2012), Cheng et al. (2014). Each sediment core was sliced on board under minimum oxygen conditions using inert nitrogen gas and sediment horizons were determined as 0-1 cm, $1-2 \mathrm{~cm}, 2-3 \mathrm{~cm}, 3-4 \mathrm{~cm}, 4-6 \mathrm{~cm}, 6-8 \mathrm{~cm}, 8-10 \mathrm{~cm}, 10-15 \mathrm{~cm}, 15-20$ $\mathrm{cm}, 20-25 \mathrm{~cm}, 25-30 \mathrm{~cm}, 30-35 \mathrm{~cm}, 35-40 \mathrm{~cm}$ and $40-45 \mathrm{~cm}$. After obtaining sliced sediments, each sample was put in a $50 \mathrm{~mL}$ falcon tube and centrifuged at $3000 \mathrm{rpm}$ for 30 min. After separation of solids, the porewater samples were extracted using syringe-coupled $\mathrm{GF} / \mathrm{F}$ filters through $0.45 \mu \mathrm{m}$ and placed in $15 \mathrm{~mL}$ falcon tubes and stored in the freezer $(-20$ ${ }^{\circ} \mathrm{C}$ ) for the analysis of nutrients. Sediment samples were also stored at $-20{ }^{\circ} \mathrm{C}$ for the determination of total carbon (TC), total organic carbon (TOC), total nitrogen (TN) and dithionite extractable reactive iron ( $\mathrm{r}-\mathrm{Fe}$ ) concentrations. Freshwater samples were collected seasonally at the downstream points of five regional rivers (Ceyhan, Seyhan, Berdan, Lamas, Göksu) in the period of 2008-2015 (Figure 2). Furthermore, domestic and industrial wastewater samples were obtained seasonally between 2006 and 2009 from the five major local facilities constructed along the NE Mediterranean region. Volume fluxes of the regional rivers and domestic and industrial wastewater facilities are presented in Table 2.

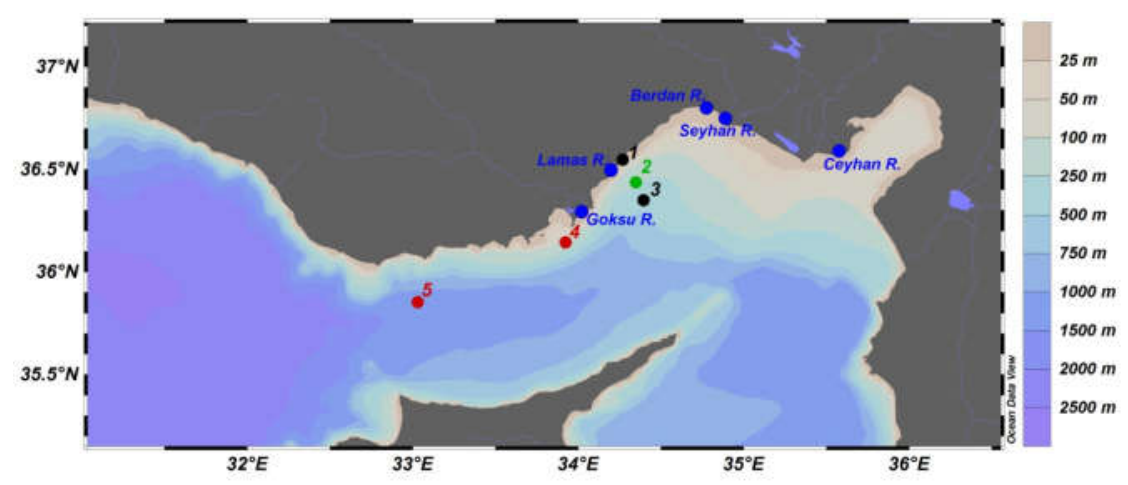

Figure 2. Locations of sediment core and river stations (black dots represent March 2018, red dots represent April 2018, one green dot represents both March and April 2018, blue dots represent river stations).

Table 1. Locations of sediment core stations with trophic status and deep water redox state

\begin{tabular}{ccccclc}
\hline Date & Station & $\begin{array}{c}\text { Latitude } \\
\text { (DD) }\end{array}$ & $\begin{array}{c}\text { Longitude } \\
\text { (DD) }\end{array}$ & $\begin{array}{c}\text { Depth } \\
\text { (m) }\end{array}$ & \multicolumn{1}{c}{ Trophic Status } & $\begin{array}{c}\text { Deepwater } \\
\text { Redox State }\end{array}$ \\
\hline 20.03 .2018 & 1 & 36.5482 & 34.2644 & 52 & Mesotrophic to Eutrophic & Oxic \\
20.03 .2018 & 2 & 36.4400 & 34.3458 & 208 & Oligotrophic & Oxic \\
20.03 .2018 & 3 & 36.3536 & 34.3811 & 323 & Oligotrophic & Oxic \\
17.04 .2018 & 4 & 36.1379 & 33.9235 & 85 & Mesotrophic to Eutrophic & Oxic \\
18.04 .2018 & 5 & 35.8520 & 33.0170 & 1165 & Ultra-oligotrophic & Oxic \\
\hline
\end{tabular}


Table 2. Annual mean volume fluxes of the regional rivers (Kocak et al. 2010) and local facilities (Tugrul et al., 2009) in the NE Mediterranean

\begin{tabular}{lc|lc}
\hline River & $\mathrm{Q}\left(\mathrm{m}^{3} / \mathrm{s}\right)$ & Wastewater & $\mathrm{Q}\left(\mathrm{m}^{3} / \mathrm{s}\right)$ \\
\hline Seyhan R. & 168 & Mersin Discharge & 0.60 \\
Ceyhan R. & 144 & Antalya Discharge & 0.45 \\
Göksu R. & 45 & İskenderun Discharge & 0.26 \\
Berdan R. & 6 & Toros Discharge & 0.014 \\
Lamas R. & 3 & KromSan Discharge & 0.006 \\
\hline
\end{tabular}

Dissolved inorganic nutrients (nitrate+nitrite, ammonium, phosphate and silicate) were determined using a Bran+Luebbe Model four-channel Autoanalyzer by standardized colorimetric methods (Grasshoff et al., 1983). The detection limits of measured nutrients are $0.02 \mu \mathrm{M}, 0.04 \mu \mathrm{M}, 0.01 \mu \mathrm{M}$ and $0.04 \mu \mathrm{M}$ for nitrate, ammonium, phosphate and reactive silicate, respectively. For the measurements of nutrients, the Oceanography laboratory of the METU-IMS has successfully participated in the international QUASIMEME Laboratory Performance Studies. TC, TOC and TN concentrations were determined by dry oxidation method using the Vario El Cube Elementar Model CHN Analyzer (UNEP/MAP, 2006). The obtained sediment samples for the TC, TOC and TN measurements were initially freezedried. Dry sediments were then powdered and sieved to homogenize the samples. For TOC analysis, nearly $30 \mathrm{mg}$ of dry and homogeneous sediment samples were put into the precombusted silver cups. Then, 5-10 $\mu \mathrm{L}$ of distilled water was added into each silver cup to wet the samples. After distilled water addition, $10 \mu \mathrm{L}$ of $20 \% \mathrm{HCl}$ (vol/vol) was added to remove inorganic carbon from the sediment samples. The $\mathrm{HCl}$ additions were continued until all the inorganic carbon was removed in the form of $\mathrm{CO}_{2}$. Then, the carbonate-free samples were dried at $60{ }^{\circ} \mathrm{C}$ for one day. After drying the sediment samples, silver cups were compacted and put into autosampler of the $\mathrm{CHN}$ analyzer. TN concentrations were also measured on $\mathrm{HCl}$-added samples and there was no significant difference between HCl-treated and untreated samples. Therefore, TC and TN analyses in sediments were performed by the same method as for the TOC analysis, but without acid addition. The reactive iron (r-Fe) concentrations were determined by colorimetric ferrozine method (Stookey, 1970; Jeitner, 2014) after dithionite ( $0.3 \mathrm{M}$ solution in a buffer containing $0.35 \mathrm{M}$ sodium acetate and $0.2 \mathrm{M}$ sodium citrate $(\mathrm{pH}=4.8)$ ) extraction of freeze-dried sediments (Kostka and Luther, 1994; Raiswell et al., 1994, Yücel et al., 2010). In this extraction technique, r-Fe refers to iron oxy(hydr)oxides, but it should be noted that dithionite can also dissolve acid volatile sulfides (ASV)-bound Fe(II) (Yücel et al., 2010). 
Porewater dissolved inorganic nutrients (nitrate+nitrite, ammonium, phosphate and silicate) were determined as described method above (Grasshoff et al., 1983). Diffusive nutrient fluxes were calculated based on Fick's First Law of Diffusion as the following equation (Al-Rousan et al., 2004; Cheng et al., 2014; Mu et al., 2017):

$\mathrm{F}=\phi \mathrm{D}_{\mathrm{s}}(\mathrm{dC} / \mathrm{dz})$

Where $\mathrm{F}$ corresponds to the diffusion flux across sediment-water interface, $\mathrm{dC} / \mathrm{dz}$ to the concentration gradient of nutrients across sediment-water interface, $\phi$ to the porosity of sediment, $D_{s}$ to the actual molecular diffusion coefficient corrected for the sediment tortuosity.

Ullman and Aller (1982) proposed an empirical formula related to the actual diffusion coefficient, $\mathrm{D}_{\mathrm{s}}$, and porosity, $\phi$ :

$\mathrm{D}_{\mathrm{s}}=\phi \mathrm{D}_{0} \quad(\phi<0.7)$

$\mathrm{D}_{\mathrm{s}}=\phi^{2} \mathrm{D}_{0} \quad(\phi>0.7)$

where $\mathrm{D}_{0}$ is the self diffusion coefficient of ions at infinite dilution. For phosphate, nitrate, nitrite and ammonium $\mathrm{D}_{0}$ values are used from Li and Gregory (1974) and for $\mathrm{Si}, \mathrm{D}_{0}$ values were used from Rebreanu et al. (2008) as $7.34 \times 10^{-6} \mathrm{~cm}^{2} \mathrm{~s}^{-1}$ for $\mathrm{PO}_{4}, 19.0 \times 10^{-6} \mathrm{~cm}^{2} \mathrm{~s}^{-1}$ for $\mathrm{NO}_{3}, 19.1 \times 10^{-6} \mathrm{~cm}^{2} \mathrm{~s}^{-1}$ for $\mathrm{NO}_{2}, 19.8 \times 10^{-6} \mathrm{~cm}^{2} \mathrm{~s}^{-1}$ for $\mathrm{NH}_{4}$ and $11.7 \times 10^{-6} \mathrm{~cm}^{2} \mathrm{~s}^{-1}$ for $\mathrm{Si}$, at 25 ${ }^{\circ} \mathrm{C}$ respectively. Porosity of surface sediments was determined by the displacement method as described by Mu et al. (2017).

Porewater diffusive, riverine and wastewater nutrient fluxes (normalized to NE Mediterranean shelf area) with atmospheric deposition (Kocak et al., 2010) were evaluated to determine internal and external nutrient fluxes to the NE Mediterranean shelf waters for further use in biogeochemical modeling and eutrophication management efforts of the oligotrophic Mediterranean Sea.

\section{Results and Discussion}

\section{Porewater nutrient dynamics in the NE Mediterranean Sea}

The core samples collected from the selected sites of the NE Mediterranean Sea (Figure 2) appeared to represent undisturbed particulate accumulations. Except for the Göksu River influenced region (St. 4), the upper parts of the sediment columns were generally light brown in color. However, at a depth of $8-10 \mathrm{~cm}$ and below this depth, the sediment profile became 
darker. The sediment core sample obtained from St. 4 had yellowish brown color throughout the sediment column having coarse-grained sediment texture.

In marine sediments, a number of organisms, such as bacteria, fungi, micro- or macro-fauna, are responsible for the aerobic degradation of organic matter in the uppermost sedimentary column where oxygen is used as electron acceptor (Jørgensen, 1996; Fenchel et al., 1998; Kristensen, 2000). In general, in this redox zone, aerobic respiration and nitrification reactions take place. In the suboxic zone and anoxic zone, anaerobic degradation of organic matter occurs stepwise by different functional types of bacteria (Fenchel et al., 1998; Kristensen, 2000). In these redox zones, denitrification, manganese oxide reduction, iron oxide reduction reactions in the suboxic zone and sulfate reduction, hydrolysis/fermentation, and carbon dioxide reduction reactions in the anoxic zone take place, respectively. Biogeochemical cycling of key nutrients $(\mathrm{N}, \mathrm{P})$ is highly coupled to oxygen concentrations and metal (Fe, Mn) cycles (Williams, 1987; Jørgensen, 1996). In the oligotrophic NE Mediterranean Sea with highly oxygenated deep waters and surface sediments, PW nutrient concentrations displayed great variability within the obtained sediment core samples. Reactive $\mathrm{PO}_{4}, \mathrm{NO}_{3}, \mathrm{NH}_{4}$ and reactive Si concentrations throughout the sediment column porewaters ranged between 0.06 and $2.30 \mu \mathrm{M}$ for reactive $\mathrm{PO}_{4}, 1.40$ and $67.62 \mu \mathrm{M}$ for $\mathrm{NO}_{3}, 0.45$ and $120.55 \mu \mathrm{M}$ for $\mathrm{NH}_{4}$ and 1.22 and $154.30 \mu \mathrm{M}$ for reactive $\mathrm{Si}$, respectively (Figure 3). PW nutrient concentrations measured in the NE Mediterranean were greater than deep water nutrient values (Y1lmaz and Tugrul., 1998) but comparable with the riverine nutrient concentrations in the study region which will further be discussed in this section. Seafloor can play a key role in rapid degradation of labile organic matter and nitrification/denitrification processes as well as other abiotic processes in the uppermost millimeters of sediment column resulting in nutrient releases from the sediments (Christensen et al., 1988; Ignatieva, 1999; Rasheed, 2004; AlRousan et al., 2004; Hille et al., 2005; Rasheed et al., 2006; Rydin et al., 2011; Cheng et al., 2014; $\mathrm{Mu}$ et al., 2017). Expectedly, $\mathrm{PW}$ nutrient concentrations $\left(\mathrm{PO}_{4}, \mathrm{NH}_{4}, \mathrm{Si}\right)$ increased with depth throughout the sediment column indicating that organic matter degradation processes took place in the first 3-10 centimeters of the sediment column in the NE Mediterranean Sea. The decrease in the nitrate concentrations with depth within the sediment column suggested denitrification process (Jørgensen, 1996) in the coastal zone (St. 1) having eutrophic properties (Tugrul et al., 2018). Though coastal zone (St. 4) influenced by the Göksu River (Figure 2), having greater volume fluxes than Lamas River (Tugrul et al., 2009; Kocak et al., 2010), displayed eutrophic properties (Tugrul et al., 2018), there was no apparent decrease in 
This paper is a non-peer reviewed preprint submitted to EarthArXiv.

nitrate concentrations within the sediment column suggested oxic respiration throughout the sediment column as also recorded in the sediment core samples obtained from shelf break (St. 3), offshore (St. 4) and reference station (St.5) (Figure 3). The sediment core samples were found oxic throughout the sediment column in the low chlorophyll regions of South Pacific Gyre having low primary production, low sedimentation rate and low organic carbon content in the uppermost centimeters of the sediment column (D'Hondt et al., 2009). In a recent study performed in the oligotrophic Eastern Mediterranean Sea, oxygen microprofiles indicated the oxygenated surficial (0-30 cmbs) sediments (Van Santvoort et al., 2002) as also inferred from the $\mathrm{NO}_{3}$ profiles obtained in this study (Figure 3 ) suggesting the availability of oxic sediment column in the uppermost 30-45 centimeters of the NE Mediterranean subseafloor having low chlorophyll concentrations in the surface layer (Tugrul et al., 2018) as also recorded in the South Pacific Gyre (D’Hondt et al., 2009). 
This paper is a non-peer reviewed preprint submitted to EarthArXiv.
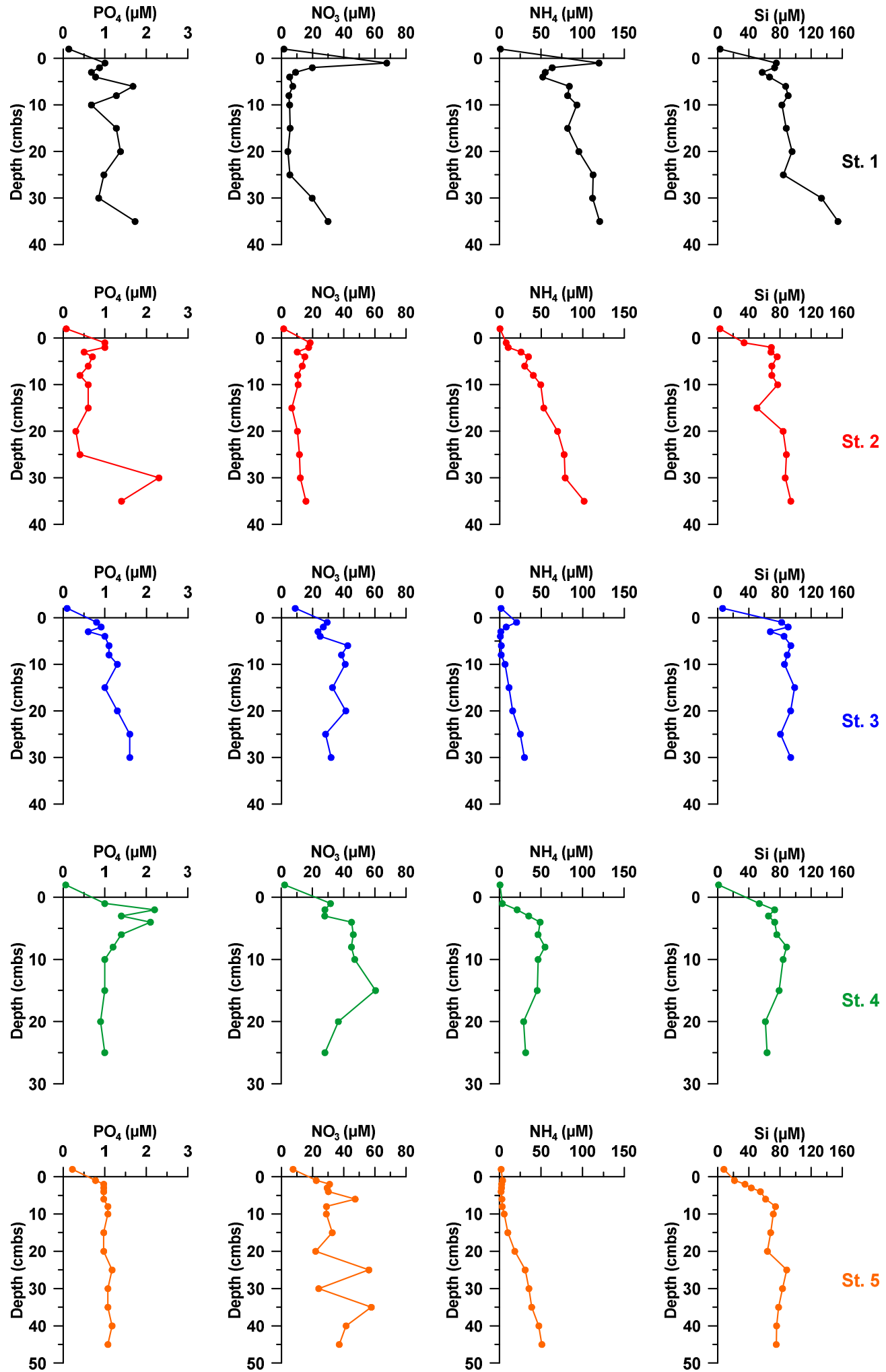

Figure 3. Sediment PW nutrient concentrations in the NE Mediterranean Sea. 


\section{Solid-phase sediment geochemistry in the NE Mediterranean Sea}

Organic matter geochemistry of the sediments has been affected by a series of redox reactions (Jørgensen, 1996) as well as terrestrial inputs of the particulate inorganic/organic matter that might be transported to offshore regions of the continental seas (Middelburg et al., 1993; Yemenicioglu and Tunc, 2013; Erdogan, 2014; Akcay, 2015, Ermiş, 2017; Deininger and Frigstad, 2019; Katz et al., 2020). In the Eastern Mediterranean Sea, surface sediment geochemistry and grain size distributions and have been studied extensively during the last decades (Eijsink et al., 2000; Yemenicioglu and Tunc, 2013; Erdogan, 2014, Akcay, 2015; Ermiş, 2017) with the limited number of studies based on sediment core samples to understand organic matter geochemistry (sedimentation, degradation, accumulation and burial of organic carbon) of the upper 25-40 cm sedimentary column (Van Santvoort et al., 2002; Katz et al., 2020). Surface sediment TC (TOC+TIC) concentrations obtained in this study varied between 3.31 and $6.79 \mathrm{mmol} / \mathrm{g}$ dw (dry weight) with maximum concentrations recorded in the uppermost centimeters of the core sample obtained from Göksu River influenced area (Figure 4) having minimum porosity at the sediment surface. On the contrary to TC distributions, lower TOC concentrations were measured in uppermost 1-2 centimeters of the core sample obtained from Göksu River influenced area $(0.26-0.32 \mathrm{mmol} / \mathrm{g} \mathrm{dw})$. Surface sediment TOC concentrations of other core samples ranged from 0.51 to $0.70 \mathrm{mmol} / \mathrm{g}$ $\mathrm{dw}$ with the greatest value recorded in the St.2 (Figure 4). Regional variations of TN distributions, ranging between $0.02-0.07 \mathrm{mmol} / \mathrm{g} \mathrm{dw}$, in the study region were very similar to TOC distributions. Terrestrial inputs of nutrients and organic matter modify the organic matter composition and concentrations and grain size distributions of sediments (Yemenicioglu and Tunc, 2013; Akcay, 2015). Moreover, differences in the sedimentation rates and currents and wave energy affect distributions of geochemical properties (De Falco et al., 2004; Katz et al., 2020). According to results of the five major river data, maximum concentrations of suspended matter (TSS) were recorded in the Göksu River among the other regional rivers (Tugrul et al., 2009) and fine-grained sediments were carried to the central and offshore regions due to regional wave actions and currents (De Falco et al., 2004; Katz et al., 2020) resulting in carbonate-rich sediment column in the Göksu River influenced coastal area (Figure 4).

The TOC and TN concentrations measured in this study were in agreement with the organic matter geochemical properties from the previous studies performed in the oligotrophic Eastern Mediterranean Sea (Eijsink et al., 2000; Erdogan, 2014, Akcay, 2015; Ermiş, 2017; 
This paper is a non-peer reviewed preprint submitted to EarthArXiv.

Katz et al., 2020). The TOC concentrations of the sediment column $(0.26-0.70 \mathrm{mmol} / \mathrm{g} \mathrm{dw}$ in the 1-45 cmbs) recorded in this study were in agreement with the TOC contents obtained from South Pacific Gyre sediment core samples $(0.14-0.43 \mathrm{mmol} / \mathrm{g} \mathrm{dw}$ in the $3 \mathrm{cmbs}-1.47 \mathrm{mbs})$ by the study of D'Hondt et al. (2009) having similar biochemical properties with the oligotrophic NE Mediterranean Sea with low chlorophyll and nutrient concentrations (Tugrul et al., 2018) suggesting that oxic respiration is the major organic matter degradation process in the uppermost sedimentary column of the oligotrophic marine environments as also observed from the oxygen microprofiles obtained from the surficial $(0-30 \mathrm{cmbs})$ Eastern Mediterranean sediments (Van Santvoort et al., 2002).

Vertical profiles of TOC concentrations and vertical profiles (in St.2 and 5) suggested that organic matter degradation occurred in the uppermost centimeters of the sediment column reaching a constant value down to $8-10 \mathrm{~cm}$ indicating refractory organic matter pool below this layer. The $\mathrm{r}-\mathrm{Fe}$ concentrations varied between 12.7-47.8 $\mu \mathrm{mol} / \mathrm{g} \mathrm{dw}$ throughout the sediment column of the obtained core samples. The results of r-Fe concentrations of this study were very similar to the recent studies performed in the NE Mediterranean surface sediments (Ermis, 2017) and Eastern Black Sea core samples (Yucel et al., 2010). Vertical profiles of rFe concentrations were very similar to observed in the TOC profiles; high concentrations in the upper sedimentary column which decreased with sediment depth suggesting organic matter degradation by iron reduction the NE Mediterranean subseafloor. These findings strongly suggested the coupling between reactive iron and organic carbon in the $\mathrm{NE}$ Mediterranean as recently explored from the studies of Ermiş (2017) and Katz et al. (2020) in the region. Further studies should be performed about sediment iron speciation and its coupling with the redox sensitive elements $(\mathrm{Mn}, \mathrm{P}, \mathrm{S}, \mathrm{U}, \mathrm{V}, \mathrm{Mo})$ to understand the intersections between sediment geochemistry (organic carbon degradation and burial) and redox sensitive porewater macro- and micro-nutrients, available for the marine organisms in the NE Mediterranean Sea. As a result, sediment porewater nutrients and solid state geochemical parameters should be measured and integrated to marine monitoring programmes to attain Good Environmental Status (GES) of the Eastern Mediterranean Sea. 
This paper is a non-peer reviewed preprint submitted to EarthArXiv.
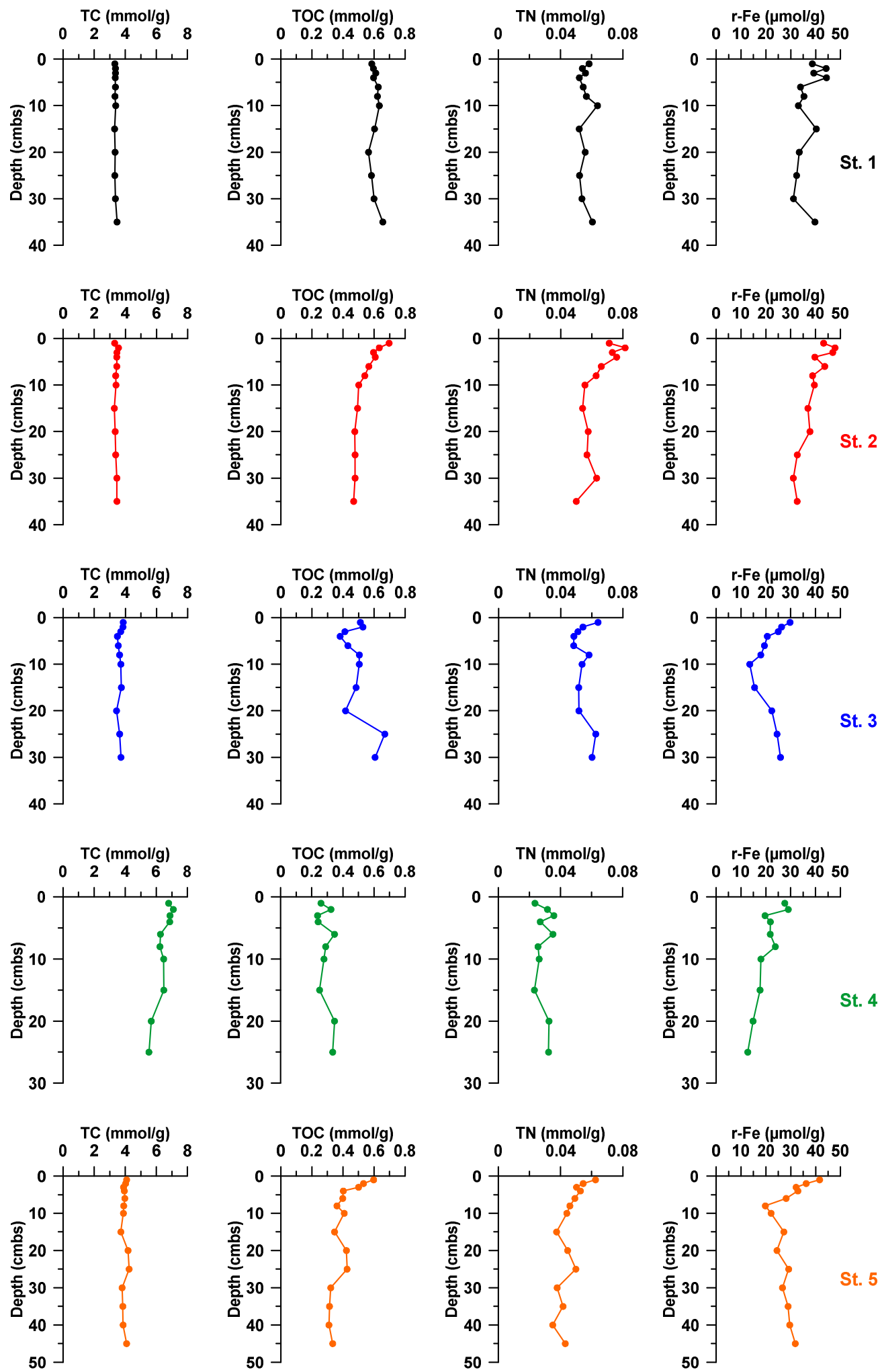

Figure 4. Sediment total carbon (TC), total organic carbon (TOC), total nitrogen (TN) and reactive iron $(\mathrm{r}-\mathrm{Fe})$ contents in the NE Mediterranean Sea. 
Vertical profiles of PW nutrients (Figure 3) and also solid-phase sediment organic matter (C, $\mathrm{N}$ ) and reactive iron concentrations (Figure 4) revealed that organic matter mineralization was occurred by oxic/aerobic respiration in the upper $30-45 \mathrm{cmbs}$ in the offshore regions of the NE Mediterranean Sea having low chlorophyll concentrations in the surface layer (Tugrul et al., 2018) and also low sedimentation rate $(0.005-0.014 \mathrm{~cm} / \mathrm{y})$ (Katz et al., 2020) which are typical for (ultra-)oligotrophic and deep-sea environments. Furthermore, there was no apparent decrease in nitrate concentrations within the sediment column also suggested oxic respiration throughout the sediment core samples obtained from shelf break (St. 3), offshore (St. 4) and reference station (St.5) (Figure 3). On the other hand, denitrification process occurred in the coastal zone (St. 1) where nitrate concentrations decreased with increasing sediment depth. Vertical profiles of r-Fe and TOC concentration indicated high concentrations in the upper sedimentary column which decreased with sediment depth suggesting organic matter degradation by iron reduction in the NE Mediterranean subseafloor. In order to understand past and future implications of the sediment biogeochemistry and the distributions of key elements incorporated into biomass (C, N, P, metals), voltammetric determination of redox-dependent elements (oxygen, hydrogen sulfide, manganese and iron) by micro-sensors should be needed for the NE Mediterranean Sea ecosystem dynamics.

\section{Riverine, wastewater, atmospheric and sediment porewater nutrient concentrations in the} NE Mediterranean Sea

The seasonal and regional averages of nutrient concentrations measured in the five regional rivers (Figure 2) for the 2008-2015 period are presented in Table 3, showing remarkable seasonal and regional variations with the peak values reached in the wet winter-spring seasons. Rivers often transport nutrients that can enrich coastal plankton communities (Farrow et al., 2019). The development of eutrophication in the coastal sites of the NE Mediterranean shelf waters has been experienced due to riverine and wastewater discharges (Dogan-Saglamtimur and Tugrul 2004; Tugrul et al., 2009; 2011; 2016; 2018). Atmospheric nutrient inputs, both dry and wet deposition, have also remarkable contribution to sustain primary production in the Northeastern Mediterranean Sea (Kocak et al., 2010; Kocak, 2015), especially in dry summer-autumn period when the volume fluxes of the regional rivers decreases. The results of riverine nutrient concentrations indicated that maximum nutrient concentrations were measured in the contaminated Seyhan and Ceyhan Rivers whilst lowest concentrations were determined in the least contaminated Lamas River having the lowest volume flux. Nutrient inputs increased in the winter-spring periods due to enhanced flow rates 
This paper is a non-peer reviewed preprint submitted to EarthArXiv.

and nutrient contents of the major rivers. Maximum concentrations of seasonal TP (12-33 $\mu \mathrm{M})$ and $\mathrm{PO}_{4}(3-29 \mu \mathrm{M})$ were recorded in Seyhan and Ceyhan Rivers. The least contaminated small Lamas River waters contained lower phosphorus concentrations (TP: 0.1-9.6 $\mu \mathrm{M} ; \mathrm{PO}_{4}$ : 0.02-1.37 $\mu \mathrm{M})$. Nitrate and reactive silicate contents of the five rivers are seasonally variable $\left(\mathrm{NO}_{3}\right.$ : 64.1-167 $\mu \mathrm{M}$; Si: 84.2-169 $\left.\mu \mathrm{M}\right)$ with the $\mathrm{Si} / \mathrm{NO}_{3}$ ratio ranging seasonally between 0.73-2.0.

Table 3. Average concentrations of dissolved inorganic nutrients in the five regional rivers between 2008 and 2015

\begin{tabular}{|c|c|c|c|c|c|c|c|}
\hline River (Discharge; $\mathrm{m}^{3} / \mathrm{s}^{*}$ ) & Season & $\begin{array}{c}\mathrm{PO}_{4} \\
(\mu \mathrm{M})\end{array}$ & $\begin{array}{l}\mathrm{NO}_{3} \\
(\mu \mathrm{M})\end{array}$ & $\begin{array}{l}\mathrm{NH}_{4} \\
(\mu \mathrm{M})\end{array}$ & $\mathrm{Si}(\mu \mathrm{M})$ & $\mathrm{Si} / \mathrm{NO}_{3}$ & $\mathrm{NO}_{3} / \mathrm{PO}_{4}$ \\
\hline \multirow{4}{*}{ Ceyhan (144) } & Autumn & 0.97 & 118.76 & 12.06 & 145.27 & 1.27 & 170.9 \\
\hline & Winter & 3.23 & 167.07 & 17.28 & 141.29 & 1.01 & 147.0 \\
\hline & Spring & 1.05 & 141.05 & 18.82 & 135.3 & 1.05 & 218.2 \\
\hline & Summer & 0.97 & 125.13 & 7.94 & 169.01 & 1.45 & 167.5 \\
\hline \multirow{4}{*}{ Seyhan (168) } & Autumn & 6.32 & 166.73 & 40.00 & 98.84 & 0.73 & 43.5 \\
\hline & Winter & 2.04 & 92.80 & 39.89 & 91.23 & 1.57 & 75.2 \\
\hline & Spring & 4.04 & 117.82 & 14.89 & 93.68 & 1.28 & 99.6 \\
\hline & Summer & 4.31 & 93.88 & 8.72 & 89.92 & 1.55 & 97.7 \\
\hline \multirow{4}{*}{ Berdan (6) } & Autumn & 2.48 & 95.86 & 12.68 & 87.55 & 1.01 & 87.5 \\
\hline & Winter & 1.57 & 97.36 & 23.03 & 127.74 & 1.47 & 115.8 \\
\hline & Spring & 1.34 & 100.44 & 12.9 & 87.35 & 0.97 & 113.6 \\
\hline & Summer & 2.22 & 84.35 & 8.39 & 88.82 & 1.12 & 69.5 \\
\hline \multirow{4}{*}{ Lamas (3) } & Autumn & 0.12 & 94.46 & 1.08 & 86.28 & 0.95 & 932.1 \\
\hline & Winter & 0.08 & 102.98 & 0.69 & 99.49 & 1.04 & 1631.6 \\
\hline & Spring & 0.28 & 93.37 & 1.84 & 84.17 & 0.96 & 991.9 \\
\hline & Summer & 0.11 & 83.96 & 1.54 & 110.14 & 1.51 & 1303.4 \\
\hline \multirow{4}{*}{ Göksu (45) } & Autumn & 0.64 & 64.11 & 10.29 & 126.94 & 2.0 & 140.8 \\
\hline & Winter & 0.53 & 66.72 & 2.82 & 101.75 & 1.74 & 171.0 \\
\hline & Spring & 0.69 & 68.17 & 3.77 & 118.26 & 1.96 & 152.9 \\
\hline & Summer & 1.05 & 72.97 & 4.24 & 108.46 & 1.67 & 237.7 \\
\hline
\end{tabular}

Wastewater nutrient concentrations were much greater than measured in the regional rivers and showed marked spatial variability (Table 4). Maximum concentrations of $\mathrm{PO}_{4}$ and $\mathrm{NH}_{4}$ were measured in the Mersin Discharge. KromSan and Toros Discharges had moderately low concentrations. Minimum nutrient concentrations were recorded in Antalya Discharge showing effective biochemical treatment in this region. Though high concentrations of wastewater nutrients recorded in the studied regions, volume fluxes of wastewater discharges were lower than riverine volume fluxes (Table 2), but still resulting in local pollution and eutrophication in the coastal areas of the NE Mediterranean as experienced in İskenderun and Mersin inner bays (Tugrul et al., 2009; 2011; 2016). 
This paper is a non-peer reviewed preprint submitted to EarthArXiv.

Table 4. Concentrations of wastewater dissolved inorganic nutrients between 2006 and 2009

\begin{tabular}{|c|c|c|c|c|c|c|c|}
\hline Wastewater (Discharge; $\mathrm{m}^{3} / \mathrm{s}^{*}$ ) & Season & $\begin{array}{c}\mathrm{PO}_{4} \\
(\mu \mathrm{M})\end{array}$ & $\begin{array}{l}\mathrm{NO}_{3} \\
(\mu \mathrm{M})\end{array}$ & $\begin{array}{l}\mathrm{NH}_{4} \\
(\mu \mathrm{M})\end{array}$ & $\begin{array}{c}\mathrm{Si} \\
(\mu \mathrm{M})\end{array}$ & $\mathrm{Si} / \mathrm{NO}_{3}$ & $\mathrm{NO}_{3} / \mathrm{PO}_{4}$ \\
\hline \multirow{4}{*}{ İskenderun Discharge (0.26) } & Autumn & 147.10 & 259.73 & 42.04 & 634.67 & 7.26 & 1.9 \\
\hline & Winter & 52.58 & 666.70 & 22.88 & 320.10 & 0.59 & 13.6 \\
\hline & Spring & 46.00 & 550.30 & 12.19 & 482.90 & 0.89 & 33.4 \\
\hline & Summer & 97.60 & 621.40 & 207.03 & 665.75 & 1.18 & 9.7 \\
\hline \multirow{4}{*}{ KromSan Discharge (0.006) } & Autumn & 0.25 & 602.25 & 110.40 & 428.00 & 0.72 & 5613.1 \\
\hline & Winter & 0.15 & 708.40 & 69.50 & 104.65 & 0.14 & 5520.8 \\
\hline & Spring & 0.29 & 327.50 & 101.50 & 142.10 & 0.76 & 2043.0 \\
\hline & Summer & 0.09 & 663.50 & 49.89 & 203.60 & 1.11 & 7372.2 \\
\hline \multirow{4}{*}{ Toros Discharge (0.014) } & Autumn & 2.36 & 1937.50 & 193.10 & 455.15 & 0.25 & 1331.1 \\
\hline & Winter & 2.02 & 1628.50 & 158.81 & 369.00 & 0.23 & 901.6 \\
\hline & Spring & 1.52 & 2021.00 & 60.25 & 539.40 & 0.27 & 2607.0 \\
\hline & Summer & 2.40 & 2026.90 & 216.73 & 321.65 & 0.15 & 847.6 \\
\hline \multirow{4}{*}{ Mersin Discharge (0.60) } & Autumn & 171.00 & 4.30 & 1828.50 & 258.50 & 64.04 & 0.03 \\
\hline & Winter & 135.55 & 94.96 & 2151.00 & 276.70 & 11.48 & 1.7 \\
\hline & Spring & 188.00 & 34.25 & 2707.00 & 281.60 & 11.84 & 0.2 \\
\hline & Summer & 174.33 & 20.79 & 1890.00 & 278.33 & 27.04 & 0.1 \\
\hline \multirow{4}{*}{ Antalya Discharge (0.45) } & Autumn & 31.40 & 360.46 & 3.38 & 350.50 & 115.97 & 17.6 \\
\hline & Winter & 83.39 & 84.40 & 155.23 & 365.10 & 13.45 & 1.3 \\
\hline & Spring & 88.25 & 500.20 & 559.33 & 319.25 & 2.58 & 14.1 \\
\hline & Summer & 73.53 & 653.20 & 97.23 & 307.33 & 4.77 & 14.6 \\
\hline
\end{tabular}

Atmospheric nutrient concentrations in aerosols determined from a long-term observation (Kocak et al., 2010) showed that water soluble reactive $\mathrm{PO}_{4}$ and $\mathrm{Si}$ concentrations ranged from 0.03 to $6.40 \mathrm{nmol} \mathrm{m}^{-3}$ for $\mathrm{PO}_{4}$ and 0.04 to $26.27 \mathrm{nmol} \mathrm{m}^{-3}$ for Si. Water soluble $\mathrm{NO}_{3}$ and $\mathrm{NH}_{4}$ concentrations varied between $0.2-258.8 \mathrm{nmol} \mathrm{m}^{-3}$ and $0.1-473.2 \mathrm{nmol} \mathrm{m}^{-3}$, respectively. For rainwater samples obtained from the same study, the volume weighted mean values for $\mathrm{PO}_{4}, \mathrm{Si}, \mathrm{NO}_{3}$ and $\mathrm{NH}_{4}$ were calculated as $0.7,1.9,44$ and $46 \mu \mathrm{M}$, respectively. comparison of atmospheric deposition (dry+wet) (Kocak et al., 2010) showed that aerosol and rainwater reactive Si concentrations measured in the NE Mediterranean Sea were much lower than measured $\mathrm{Si}$ concentrations in the riverine and wastewater concentrations, but $\mathrm{PO}_{4}$ and $\mathrm{NO}_{3}$ concentrations were comparable to measured in the rivers. Aerosol and wastewater samples were highly enriched by $\mathrm{NH}_{4}$ compared to riverine $\mathrm{NH}_{4}$ concentrations.

\section{Comparison of internal and external nutrient fluxes and their elemental compositions (Si/N/P) in the Northeastern Mediterranean Sea}

In this study, the quantification of all source terms of nutrients (rivers, wastewaters, PW diffusive nutrient fluxes, atmospheric inputs (based on the study performed by Kocak et al. (2010)) was made to assess nutrient loads for the NE Mediterranean Sea having oligotrophic properties in its offshore waters (UNEP, 1989; Y1lmaz and Tugrul, 1998; Kress and Herut, 
2001; Krom et al., 2004; Tugrul et al., 2016; 2018). Since riverine and wastewater nutrient inputs have highly affected coastal zones of the NE Mediterranean, fluxes were normalized to the area of shelf regions of the NE Mediterranean.

It should be noted that the total nutrient fluxes were assumed to be greater than diffusive nutrient fluxes due to other processes at sediment-water interface such as bioturbation, bioirrigation (Barbanti et al., 1992) and also biotic/abiotic processes for the organic matter degradation in the uppermost millimeters of sediment column (Christensen et al., 1988; Ignatieva, 1999; Rasheed, 2004; Al-Rousan et al., 2004; Hille et al., 2005; Rasheed et al., 2006; Rydin et al., 2011; Cheng et al., 2014; Mu et al., 2017). In this study, calculated diffusive nutrient fluxes based on the Fick's First Law of Diffusion presented in Table 5 indicated remarkably high nutrient fluxes from the sediment into the deep waters of the NE Mediterranean Sea. Maximum nutrient fluxes were calculated in the river-influenced coastal region indicated that human-induced pressures not only affect the coastal surface waters, but also affect sediment porewater nutrient dynamics due to increase in primary productivity and hence sedimentation in the eutrophic coastal areas. Expectedly, lower PW diffusive nutrient fluxes were calculated in the oligotrophic offshore regions of the NE Mediterranean (Table 5).

Table 5. Diffusive nutrient fluxes from sediment to the deep waters in the NE Mediterranean Sea

\begin{tabular}{ccccc}
\hline Station & $\begin{array}{c}\mathrm{PO}_{4} \\
\left(\mathrm{mmol} \mathrm{m}^{-2} \mathrm{yr}^{-1}\right)\end{array}$ & $\begin{array}{c}\mathrm{NO}_{3} \\
\left(\mathrm{mmol} \mathrm{m}^{-2} \mathrm{yr}^{-1}\right)\end{array}$ & $\begin{array}{c}\mathrm{NH}_{4} \\
\left(\mathrm{mmol} \mathrm{m}^{-2} \mathrm{yr}^{-1}\right)\end{array}$ & $\begin{array}{c}\mathrm{Si} \\
\left(\mathrm{mmol} \mathrm{m}^{-2} \mathrm{yr}^{-1}\right)\end{array}$ \\
\hline 1 & 0.57 & 66.87 & 46.23 & 77.20 \\
2 & 0.36 & 18.55 & 12.79 & 50.77 \\
3 & 0.42 & 50.11 & 22.30 & 60.81 \\
4 & 0.35 & 26.50 & 11.71 & 36.62 \\
5 & 0.36 & 43.43 & 2.81 & 28.48 \\
\hline
\end{tabular}

Redox-dependent benthic nutrient fluxes would enhance algal production (Christensen et al., 1988; Ignatieva, 1999; Rasheed et al., 2006). In a study conducted in the oligotrophic Eastern Mediterranean continental shelf, the phosphate and nitrate fluxes into the water column supported as much as $11.7 \%$ and $2 \%$ of the phytoplankton $\mathrm{P}$ and $\mathrm{N}$ demand, respectively (Christensen et al., 1988). Furthermore, it was observed that porewater nutrient concentrations revealed reduced conditions in these shelf sediments where nitrate depletion was seen in the uppermost centimeters of the collected sediment cores (Jørgensen, 1996) as also experienced in NE Mediterranean shelf region by this study. In this study, calculated diffusive nutrient fluxes were very similar to the study of Christensen et al. (1988) and Rasheed et al. (2006) performing their studies in the oligotrophic regions, but much lower than the studies by 
Ignatieva (1999) and Noffke et al. (2012) where the studies were conducted in the highly eutrophic regions having suboxic and anoxic/sulfidic deep waters.

Mean annual nutrient fluxes in the NE Mediterranean shelf region were calculated (Table 6) for both external and internal sources and the contribution of each source term were quantified in the NE Mediterranean Sea (Figure 5). In the NE Mediterranean shelf waters, total nutrient fluxes for $\mathrm{PO}_{4}, \mathrm{NO}_{3}, \mathrm{NH}_{4}$ and $\mathrm{Si}$ were calculated as 6.80, 303.71, 88.90 and $221.94 \mathrm{mmol} \mathrm{m}^{-2} \mathrm{yr}^{-1}$, respectively. The results of the source assessment of nutrient fluxes to the NE Mediterranean Sea indicated that the major contribution of nutrients to the NE Mediterranean coastal area was assigned as riverine nutrient inputs for phosphate, nitrate and reactive silicate. Atmospheric inputs (Kocak et al., 2010) have remarkable contribution for the ammonium fluxes to the NE Mediterranean having limited inputs in terms of reactive silicate (Figure 5). Contribution of wastewater phosphate and ammonium fluxes to the NE Mediterranean was also markedly high and much greater than wastewater nitrate and silicate inputs. In this study, contribution of PW diffusive nutrient fluxes to the total nutrient fluxes in the NE Mediterranean Sea was calculated as $5.8 \%$ for $\mathrm{PO}_{4}, 12 \%$ for $\mathrm{NO}_{3}, 19 \%$ for $\mathrm{NH}_{4}$ and $22 \%$ for reactive $\mathrm{Si}$, respectively (Figure 5 ). The increase in dissolved inorganic phosphorous and iron concentrations in the eutrophic and suboxic/anoxic/sulfidic regions is highly related to redox conditions in the marine environment as the role of sediments in these regions has important for dissolved iron, inorganic phosphate and ammonium sources to the bottom water (Noffke et al., 2012). Though dissolved oxygen concentrations were at saturation levels in the NE Mediterranean upper layer (Tugrul et al., 2016; 2018) with highly oxygenated deep waters, contribution of PW diffusive nutrient fluxes were markedly high. Contribution of diffusive nutrient inputs was much greater than wastewater nutrient inputs for nitrate, ammonium and reactive silicate, but lower than phosphate due probably to adsorption of phosphate onto metal oxides (Mortimer, 1942 as referenced in Nteziryayo and Danielsson, 2018) in the oxygenated surface sediments of the NE Mediterranean Sea.

Table 6. External and internal nutrient inputs for the NE Mediterranean Sea (Atmospheric nutrient fluxes were retrieved from the study of Kocak et al. (2010).)

\begin{tabular}{lcccccc}
\hline Source & $\begin{array}{c}\mathrm{PO}_{4} \\
\left(\mathrm{mmol} \mathrm{m}^{-2} \mathrm{yr}^{-1}\right)\end{array}$ & $\begin{array}{c}\mathrm{NO}_{3} \\
\left(\mathrm{mmol} \mathrm{m}^{-2} \mathrm{yr}^{-1}\right)\end{array}$ & $\begin{array}{c}\mathrm{NH}_{4} \\
\left(\mathrm{mmol} \mathrm{m}^{-2} \mathrm{yr}^{-1}\right)\end{array}$ & $\begin{array}{c}\mathrm{Si} \\
\left(\mathrm{mmol} \mathrm{m}^{-2} \mathrm{yr}^{-1}\right)\end{array}$ & $\begin{array}{c}\mathrm{Si} / \mathrm{NO}_{3} \\
(\mathrm{Molar})\end{array}$ & $\begin{array}{c}\mathrm{NO}_{3} / \mathrm{PO}_{4} \\
(\mathrm{Molar})\end{array}$ \\
\hline Sediment & 0.39 & 36.3 & 17.2 & 48.0 & 1.32 & 91.8 \\
\hline Atmospheric & 0.69 & 125.0 & 38.0 & 1.43 & 0.01 & 181.2 \\
\hline River & 4.45 & 139.4 & 22.4 & 168.9 & 1.21 & 31.3 \\
\hline Wastewater & 1.27 & 3.1 & 11.3 & 3.66 & 1.19 & 2.4 \\
\hline Total & 6.80 & 303.71 & 88.90 & 221.94 & 0.73 & 44.7 \\
\hline
\end{tabular}




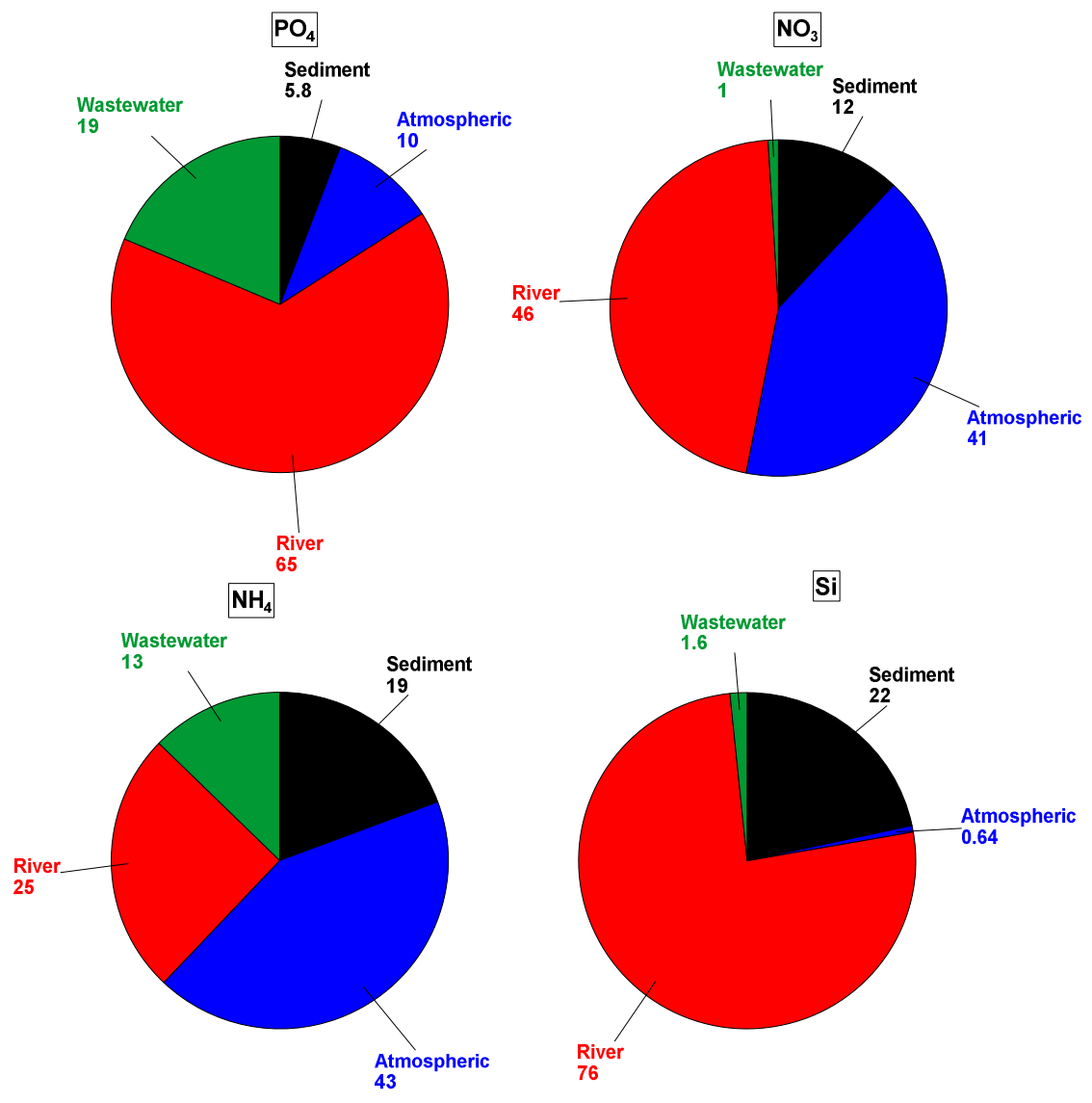

Figure 5. Contribution of sources of nutrients for the NE Mediterranean shelf waters (\%).

The eastern Mediterranean deep water is characterized by high N/P molar ratios (Krom et al., 1991, Y1lmaz and Tugrul, 1998) due to internal and external sources with high N:P molar ratios (Krom et al., 2004; Kocak et al., 2010) as well as lack of feedback mechanisms for bioavailable $\mathrm{N}$ through denitrification in the sediment and water column (Krom et al., 2004). Positive nutrients (Si, N, P) fluxes indicated sediment in the NE Mediterranean shelf acts as a source for nutrients. The N/P molar ratios calculated for the regional rivers, atmospheric deposition and sediment porewaters (Table 6, Figure 6), except for wastewaters, were greater than classical Redfield Ratio (N/P=16), reflecting high $\mathrm{N} / \mathrm{P}$ molar ratios in the Mediterranean deep waters (Krom et al., 1991, Y1lmaz and Tugrul, 1998). As a result, it can be concluded benthic nutrient fluxes with high N/P molar ratios and the nutrient dynamics at the sedimentwater interface in the NE Mediterranean shelf region might be also one of the reasons addressing why the eastern Mediterranean is P-limited as also experienced in the previous studies (Krom et al., 1991; 2004; Y1lmaz and Tugrul, 1998; Tufekci et al., 2013; Tugrul et al., $2011 ; 2016 ; 2018)$. It should be also noted that low $\mathrm{Si} / \mathrm{N}\left(\mathrm{Si} / \mathrm{NO}_{3}=0.73\right)$ and high $\mathrm{N} / \mathrm{P}$ 
$\left(\mathrm{NO}_{3}: \mathrm{PO}_{4}=44.7\right)$ molar ratios in the total nutrient inputs (Table 6) compared to classical Redfield Ratio are very likely to modify phytoplankton composition and abundance in the phosphorus deficient NE Mediterranean productive shelf waters leading to development of mesotrophic/eutrophic conditions in the NE Mediterranean Sea. Therefore, quantification of both internal and external nutrient inputs is needed for further use in biogeochemical modeling of the oligotrophic Mediterranean Sea and its ecosystem dynamics which are of critical importance to attain Good Environmental Status (GES) for the Eastern Mediterranean Sea.
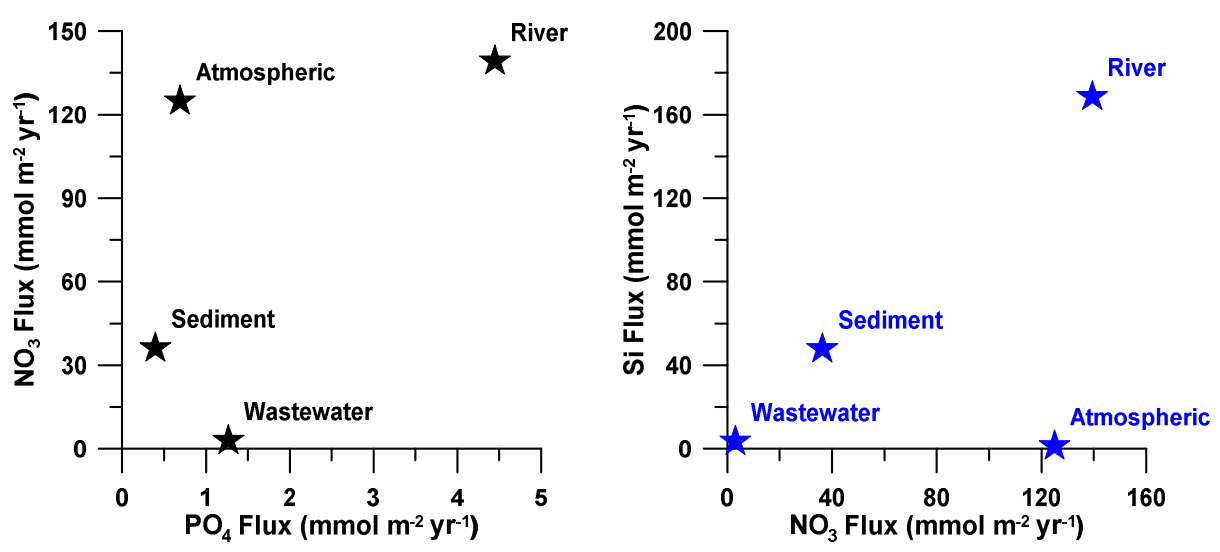

Figure 6. N vs. P and Si vs. N plots of the nutrient fluxes in the NE Mediterranean Sea.

\section{Conclusions}

Sediment porewater nutrient ( $\mathrm{Si}, \mathrm{N}, \mathrm{P}$ ) and sediment organic matter biogeochemistry were studied in the NE Mediterranean Sea. Porewater diffusive nutrient fluxes were also calculated for the comparison with the external nutrient inputs in the NE Mediterranean shelf region. The study results indicated a series of redox reactions; organic matter mineralization was occurred by oxic/aerobic respiration in the upper $30-45 \mathrm{cmbs}$ in the offshore regions of the NE Mediterranean Sea having low surface water chlorophyll concentrations and low sedimentation rates which are typical for (ultra-)oligotrophic and deep-sea environments whilst denitrification process was occurred in the river influenced coastal region. Vertical profiles of the reactive iron concentrations were also suggested microbial iron reduction in the NE Mediterranean subseafloor. Determination of redox-dependent benthic nutrient fluxes is critical for the management of eutrophication status of coastal marine ecosystems since high nutrient inputs from the surface sediment can support benthic community and productivity in highly polluted sites of the inner bays. In this study, therefore, redox-dependent benthic nutrient fluxes as an internal nutrient input were determined in the NE Mediterranean shelf 
This paper is a non-peer reviewed preprint submitted to EarthArXiv.

waters. Riverine and wastewater nutrient fluxes were also determined in the NE Mediterranean Sea and using atmospheric (wet+dry deposition) nutrient fluxes, all the external inputs were quantified and compared with the benthic nutrient fluxes. Results of this study indicated remarkable contribution of porewater diffusive nutrient fluxes to the total nutrient budget in the NE Mediterranean Sea. Lower Si/N and higher N/P molar ratios in the total nutrient inputs are very likely to modify phytoplankton composition and abundance in the phosphorus deficient NE Mediterranean productive shelf waters leading to development of mesotrophic/eutrophic conditions. Another important source term of allochthonous nutrients is the submarine groundwater discharge which is not determined in the scope of this study though its contribution was markedly high in the Mediterranean Sea (Rodellas et al., 2015). The magnitude of volume fluxes, the nutrient concentrations and composition of the submarine groundwater discharge in the NE Mediterranean Sea located on one of the widest shelf areas should be needed for further use in biogeochemical modeling of the oligotrophic Mediterranean Sea and its ecosystem dynamics. It is also important that sediment porewater nutrients and solid-phase geochemical parameters should be determined and integrated to marine monitoring programmes to attain Good Environmental Status (GES) of the Eastern Mediterranean Sea.

\section{Acknowledgements}

This study has been supported by DEKOSIM (Centre for Marine Ecosystem and Climate Research, Project Code BAP-08-11-DPT.2012K120880) Project and TUBA-GEBIP Program of the Turkish Academy of Sciences. Riverine and wastewater samples were obtained by the projects (107G066, 111G152) supported by the Scientific and Technological Research Council of Turkey (TUBITAK). We would like to thank the cruise participants, crew of R/V Bilim-2 and METU-IMS technical personnel for helping biogeochemical sampling and analyses.

\section{References}

Akcay, I. 2015. Spatial variations of Particulate Organic Matter (POM) composition and concentrations in surface waters and sediments of the Mersin Bay. Dissertation, Institute of Marine Sciences, Middle East Technical University.

Al-Rousan, S., Rasheed, M., Badran, M., 2004. Nutrient diffusive fluxes from sediments in the northern Gulf of Aqaba, Red Sea. Scientia Marina, 68(4), 483-490. 
Barbanti, A., Ceccherelli, V. U., Frascari, F., Reggiani, G., Rosso, G., 1992. Nutrient regeneration processes in bottom sediments in a Po delta lagoon (Italy) and the role of bioturbation in determining the fluxes at the sediment-water interface. Hydrobiologia, 228(1), $1-21$.

Cheng, X., Zeng, Y., Guo, Z., Zhu, L., 2014. Diffusion of nitrogen and phosphorus across the sediment-water interface and in seawater at aquaculture areas of Daya Bay, China. International journal of environmental research and public health, 11(2), 1557-1572.

Christensen, J.P., Goldsmith, V., Walline, P., Schneller, A., El Sayed, S.Z., 1988. Sedimentary nutrient regeneration on the oligotrophic Eastern Mediterranean continental shelf. Oceanologica Acta, Special issue.

De Falco, G., Magni, P., Teräsvuori, L.M.H., Matteucci, G., 2004. Sediment grain size and organic carbon distribution in the Cabras lagoon (Sardinia, western Mediterranean). Chemistry and Ecology, 20(sup1), 367-377.

Deininger, A., Frigstad, H., 2019. Reevaluating the role of organic matter sources for coastal eutrophication, oligotrophication and ecosystem health. Frontiers in Marine Science, 6, 210.

D'Hondt, S., Spivack, A.J., Pockalny, R., Ferdelman, T.G., Fischer, J.P., Kallmeyer, J.,Abrams, L.J., Smith, D.C., Graham, D., Hasiuk, F., Schrum, H., Stancin, A.M., 2009. Subseafloor sedimentary life in the South Pacific Gyre. PNAS 106, 11651-11656.

Dogan-Saglamtimur, N., Tugrul, S., 2004. Effect of riverine nutrients on coastal water ecosystems: A case study from the Northeastern Mediterranean Shelf. Fresenius Environmental Bulletin, 13, 1288-1294.

Eijsink, L.M., Krom, M.D., Herut, B., 2000. Speciation and burial flux of phosphorus in the surface sediments of the eastern Mediterranean. American Journal of Science, 300(6), 483503.

Erdogan, E., 2014. Distribution of particulate organic matter, its elemental composition $(\mathrm{C} / \mathrm{N} / \mathrm{P})$ and variation with environmental factors in the shelf waters and sediments in the northeastern Mediterranean (Mersin Bay). Dissertation, Institute of Graduate School of Natural and Applied Sciences, Mersin University.

Ermis, E. 2017. Spatial variations of seafloor iron cycle in Cilician basin (Eastern Mediterranean). Dissertation, Institute of Marine Sciences, Middle East Technical University. 
Farrow, C.R., Ackerman, J.D., Smith, R.E., Snider, D., 2019. Riverine transport and nutrient inputs affect phytoplankton communities in a coastal embayment. Freshwater Biology.

Fenchel, T., King, G.M., Blackburn, T.H., 1998. Bacterial Biogeochemistry: the Ecophysiology of Mineral Cycling. Academic Press, San Diego: 307 pp.

Ferreira, J.G., Andersen, J.H., Borja, A., Bricker, S.B., Camp, J., Cardoso da Silva, M., Garcés, E., Heiskanen, A.S., Humborg, C., Ignatiades, L., Lancelot, C., Menesguen, A., Tett, P., Hoepffnerm, N., Claussen, U., 2011. Overview of eutrophication indicators to assess environmental status within the European Marine Strategy Framework Directive. Estuarine, Coastal and Shelf Science. 93, 117-131.

Gao, Z., Zheng, X. L., Li, W., Song, H., 2008. Determination of nutrient fluxes across the sediment-water interface in a nitrate-rich reservoir. In: Bioinformatics and Biomedical Engineering, 2008. ICBBE 2008. The 2nd International Conference on. IEEE, 2008. p. 33193322.

Grasshoff, K., Ehrhardt, M., Kremling, K., 1983. Determination of nutrients. In: Methods of Seawater Analysis ( $2^{\text {nd }}$ ed.), Verlag Chemie Gmbh, Weiheim, Germany, pp. 125-188.

Hille, S., Nausch, G., Leipe, T., 2005. Sedimentary deposition and reflux of phosphorus (P) in the Eastern Gotland Basin and their coupling with $\mathrm{P}$ concentrations in the water column. Oceanologia, 47(4).

Ignatieva, N. V., 1999. Nutrient exchange across the sediment-water interface in the eastern Gulf of Finland. Boreal environment research, 4(4), 295-306.

Jeitner, T.M., 2014. Optimized ferrozine-based assay for dissolved iron. Analytical biochemistry, 454, 36-37.

Jørgensen, B.B., 1996. Material flux in the sediment. Eutrophication in coastal marine ecosystems, 115-135.

Katz, T., Weinstein, Y., Alkalay, R., Biton, E., Toledo, Y., Lazar, A., Zlatkin, O., Soffer, R., Rahav, E., Sisma-Ventura, G., Bar, T., Ozer, T., Gildor, H., Almogi-Labin, A., Kanari, M., Berman-Frank, I., Herut, B., 2020. The first deep-sea mooring station in the eastern Levantine basin (DeepLev), outline and insights into regional sedimentological processes. Deep Sea Research Part II: Topical Studies in Oceanography, 171, 104663. 
This paper is a non-peer reviewed preprint submitted to EarthArXiv.

Kocak, M., 2015. Solubility of Atmospheric Nutrients over the Eastern Mediterranean: Comparison between Pure-Water and Sea-Water, Implications Regarding Marine Production, Turk. J. Fish. Aquat., Sci, 15, 59-71.

Kocak, M., Kubilay, N., Tugrul, S., Mihalopoulos, N., 2010. Atmospheric nutrient inputs to the northern levantine basin from a long-term observation: sources and comparison with riverine inputs. Biogeosciences, 7, 12, 4037-4050.

Kostka, J.E., Luther III, G.W., 1994. Partitioning and speciation of solid phase iron in saltmarsh sediments. Geochimica et Cosmochimica Acta, 58(7), 1701-1710.

Kress, N., Herut, B., 2001. Spatial and seasonal evolution of dissolved oxygen and nutrients in the Southern Levantine Basin (Eastern Mediterranean Sea). Chemical characterization of the water masses and inferences on the N:P ratios. Deep-Sea Research I, 48, 2347-2372.

Kristensen, E., 2000. Organic matter diagenesis at the oxic/anoxic interface in coastal marine sediments, with emphasis on the role of burrowing animals. In Life at interfaces and under extreme conditions (pp. 1-24). Springer, Dordrecht.

Krom, M.D., Herut, B., Mantoura, R.F.C., 2004. Nutrient budget for the Eastern Mediterranean: Implications for phosphorus limitation. Limnology and Oceanography, 49(5), 1582-1592.

Krom, M.D., Kress, N., Brenner, S., Gordon, L.I., 1991. Phosphorus limitation of primary productivity in the eastern Mediterranean Sea. Limnology and Oceanography, 36(3), 424-432.

Li, Y.-H., Gregory, S., 1974. Diffusion of ions in sea water and in deep-sea sediments. Geochim. Cosmochim. Acta 38 (5), 703-714.

Malmaeus, M., Rydin, E., Jonsson, P., Lindgren, D., Karlsson, M., 2012. Estimating the amount of mobile phosphorus in Baltic coastal soft sediments of central Sweden. Boreal environment research, 17(6), 425-436.

Middelburg, J.J., Vlug, T., Jaco, F., Van der Nat, W.A.,1993. Organic matter mineralization in marine systems. Global and Planetary Change, 8(1-2), 47-58.

Mortimer, C.H., 1942. The exchange of dissolved substances between mud and water in lakes. The Journal of Ecology, 147-201. 
Mu, D., Yuan, D., Feng, H., Xing, F., Teo, F.Y., Li, S., 2017. Nutrient fluxes across sedimentwater interface in Bohai Bay Coastal Zone, China. Marine pollution bulletin, 114(2), 705-714.

Noffke A., Hensen C., Sommer S., Scholz F., Bohlen L., Mosch T., Graco M., Wallmann K., 2012. Benthic iron and phosphorus fluxes across the Peruvian oxygen minimum zone. Limnol. Oceanogr. 57, 851-867.

Nteziryayo, L.R., Danielsson, Å., 2018. Sediment DSi and DIP fluxes under changing oxygen availability in bottom waters. Boreal Environment Research, 23, 159-174.

Raiswell, R., Canfield, D.E., Berner, R. A., 1994. A comparison of iron extraction methods for the determination of degree of pyritisation and the recognition of iron-limited pyrite formation. Chemical Geology, 111(1-4), 101-110.

Rasheed, M., 2004. Nutrient Fluxes from sediments of the northern Gulf of Aqaba under various anthropogenic activities. Lebanese science journal/Journal scientifique libanais, 5(1), 3-16.

Rasheed, M., Al-Rousan, S., Manasrah, R., Al-Horani, F., 2006. Nutrient fluxes from deep sediment support nutrient budget in the oligotrophic waters of the Gulf of Aqaba. Journal of oceanography, 62(1), 83-89.

Rebreanu, L., Vanderborght, J.P., Chou, L., 2008. The diffusion coefficient of dissolved silica revisited. Marine chemistry, 112(3), 230-233.

Rodellas, V., Garcia-Orellana, J., Masqué, P., Feldman, M., Weinstein, Y., 2015. Submarine groundwater discharge as a major source of nutrients to the Mediterranean Sea. Proceedings of the National Academy of Sciences, 112(13), 3926-3930.

Rydin, E., Malmaeus, J.M., Karlsson, O.M., Jonsson, P., 2011. Phosphorus release from coastal Baltic Sea sediments as estimated from sediment profiles. Estuarine, Coastal and Shelf Science, 92(1), 111-117.

Sommer, S., Clemens, D., Yücel, M., Pfannkuche, O., Hall, P.O.J., Almroth-Rosell, E., Schulz-Vogt, H.N., Dale, A.W., 2017. Major bottom water ventilation events do not significantly reduce basin-wide benthic $\mathrm{N}$ and $\mathrm{P}$ release in the Eastern Gotland Basin (Baltic Sea). Frontiers in Marine Science, 4(18).

Stookey, L.L., 1970. Ferrozine-A new spectrophotometric reagent for iron. Analytical chemistry, 42(7), 779-781. 
Sundby, B., Gobeil, C., Silverberg, N., Alfonso, M., 1992. The phosphorus cycle in coastal marine sediments. Limnology and oceanography, 37(6), 1129-1145.

Tufekçi, V., Kuzyaka, E., Tufekçi, H., Avaz, G., Günay, A.S., Tuğrul, S. 2013. Determination of limited nutrients in the Turkish coastal waters of the Mediterranean and Aegean Seas. J. Black Sea/Mediterranean Environment Vol. 19, No. 3: 299311.

Tugrul, S., Kuçuksezgin, F., Yemenicioglu, S. Uysal, Z., 2009: Long Term Biomonitoring, Trend and Compliance Monitoring Program in Coastal Areas from Aegean, Northeastern Mediterranean and Eutrophication Monitoring in Mersin Bay (MEDPOL Phase IV). Ministry of Environment and Forestry, Ankara.

Tugrul, S., Ozhan, K., Akcay, I., 2018. Assessment of trophic status of the northeastern Mediterranean coastal waters: eutrophication classification tools revisited. Environ Sci Pollut Res, https://doi.org/10.1007/s11356-018-2529-6.

Tugrul, S., Uysal, Z., Erdogan, E., Yucel, N., 2011. Changes of eutrofication indicator parameters (TP, DIN, Chl-a and TRIX) in the cilician basin (Northeast Mediterranean). Ekoloji, 20(80), 33-41.

Tugrul, S., Yucel, N., Akcay, I., 2016. Chemical oceanography of north eastern Mediterranean. In: The Turkish part of the Mediterranean Sea; Marine Biodiversity, Fisheries, Conservation and Governance. (Turan, C., Salihoglu, B., Ozbek, E.O. and Ozturk, B). Turkish Marine Research Foundation (TUDAV), Publication No: 43, Istanbul, Turkey, 15-29.

Ullman, W. J., Aller, R.C., 1982. Diffusion coefficients in nearshore marine sediments. Limnology and Oceanography, 27(3), 552-556.

UNEP, 1989: State of the Mediterranean Marine Environment. MAP Technical Series No. 28, UNEP, Athens.

UNEP/MAP, 2006. Methods for sediment sampling and analysis, Review Meeting of MED POL - Phase III Monitoring Activities, Athens.

Vahtera, E., Conley, D.J., Gustafsson, B.G., Kuosa, H., Pitkänen, H., Savchuk, O.P., Tamminen, T., Viitasalo, M., Voss, M., Wasmund, N., Wulff, F., 2007. Internal ecosystem feedbacks enhance nitrogen-fixing cyanobacteria blooms and complicate management in the Baltic Sea. Ambio 36: 186-194. 
This paper is a non-peer reviewed preprint submitted to EarthArXiv.

Van Santvoort, P.J.M., De Lange, G.J., Thomson, J., Colley, S., Meysman, F.J.R., Slomp, C.P., 2002. Oxidation and origin of organic matter in surficial Eastern Mediterranean hemipelagic sediments. Aquatic Geochemistry, 8(3), 153-175.

Williams, G.R., 1987. The coupling of biogeochemical cycles of nutrients. Biogeochemistry, $4(1), 61-75$.

Yemenicioglu, S., Tunc, S.C., 2013. Geology and Geochemistry of Recent Sediments from the Mediterranean Sea: Sediment Texture of Northeastern Mediterranean Basin. Open Journal of Geology, 3, 371-378.

Y1lmaz, A., Tugrul, S., 1998. The effect of cold- and warm- core eddies on the distribution and stoichiometry of dissolved nutrients in the northeastern Mediterranean. Journal of Marine Systems, 16, 253-268.

Yücel, M., Konovalov, S.K., Moore, T.S., Janzen, C.P., Luther III, G.W., 2010. Sulfur speciation in the upper Black Sea sediments. Chemical Geology, 269(3-4), 364-375. 